\title{
Mixed cortico-medullary adrenal carcinoma in children: looks are deceptive!!
}

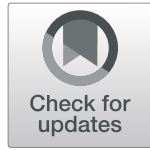

Arti Khatri ${ }^{1}$, Nidhi Mahajan ${ }^{1 *}$, Niyaz Ahmed Khan ${ }^{2}$ and Natasha Gupta ${ }^{3}$

\begin{abstract}
Background: Mixed cortico-medullary adrenal carcinoma (MCMAC) is an extremely rare entity with scarce literature on its cytomorphology.

Case presentation: A 2-year-old girl presented with abdominal pain for 3 days and a past history of fever with significant weight loss. On examination, a non-tender left hypochondrial firm mass and an enlarged left supraclavicular node were found. Twenty-four-hour urinary levels of VMA were marginally high. Contrast-enhanced computed tomography of the abdomen showed a suprarenal heterogeneous mass encasing major vessels. Aspiration cytology of both mass and node showed similar features comprising a predominant population of singly scattered large cells with moderate cytoplasm, eccentric nucleus and prominent nucleolus in a necrotic background. Tumour cells expressed Synaptophysin and Melan-A. In view of increasing respiratory distress, debulking surgery was performed, and histopathology of the specimen revealed the presence of both malignant medullary and cortical components supported by immunohistochemistry making a final diagnosis of MCMAC. The patient succumbed to death in the postoperative period. The cytology slides were reviewed and were seen to show a dual cell population.

Conclusion: Coexistent malignant cortical and medullary tumour of the adrenal gland is the first case reported in the paediatric age group in the literature with only three previous case reports in adults.
\end{abstract}

Keywords: Adrenal, Tumour, Pheochromocytoma, Synaptophysin, Melan-A, Case report

\section{Background}

Mixed cortico-medullary tumours of the adrenal gland are usually benign tumours affecting females with low mortality or metastasis $[1,2]$. The cortex and medulla of the adrenal gland are different in their embryological origin, functions, gross and microscopic features. So, the tumours arising from both also show various clinical manifestations and biological behaviours. Adenomas are the most characteristic tumours of the adrenal cortex, and carcinoma of this site is rare. On the contrary, medullary tumours are usually pheochromocytoma, which can rarely be malignant. Composite tumours of the cortex and medulla within the adrenal gland are extremely

\footnotetext{
* Correspondence: nidhi0615@gmail.com

'Department of Pathology, Chacha Nehru Bal Chikitsalaya, Room No.404,

Fourth Floor, Geeta Colony, Delhi 110031, India

Full list of author information is available at the end of the article
}

uncommon and generally benign $[3,4]$. An extensive literature search revealed only three malignant mixed tumours affecting adults and the elderly, this being the first in children [4]. Moreover, the cytological features of this entity have not been reported before. Fine needle aspiration cytology (FNAC) being the modality of choice in abdominal tumours can aid in early diagnosis and prognostication of this tumour, thereby raising the need to increase awareness of this infrequent entity amongst pathologists and paediatricians.

\section{Case presentation}

A 2-year-old girl presented with low-grade fever since 1 month and a constant dull aching abdominal pain for the past 3 days. No history of nausea, vomiting, melena or jaundice was present. The patient had lost 8 pounds weight in 1 month. Birth and immunization history were 
uneventful. No significant family history. Per abdomen, an ill-defined, non-tender firm mass was palpable in the left hypochondrium crossing the midline without hepatomegaly. The patient also had an enlarged firm left supraclavicular lymph node. The significant laboratory investigations showed $24 \mathrm{~h}$ urinary levels of vanillylmandelic acid (VMA) $2.76 \mathrm{mg} / 24 \mathrm{~h}$ (normal $<2.20$ ), urinary ketones-positive $(100 \mathrm{mg} / \mathrm{dL})$ and raised erythrocyte sedimentation rate (ESR) $94 \mathrm{~mm} / \mathrm{h}$. With a clinical impression of neuroblastoma, a contrast-enhanced computed tomography (CECT) chest and abdomen were done; the latter showed a multicystic heterogeneously enhancing mass in the suprarenal region with stippled, amorphous calcifications and multiple vascular channels coursing through it. The mass encased the aorta, its branches and bilateral renal vessels with anterior displacement of the pancreas and lateral displacement of the kidney (Fig. 1A). CECT was also suggestive of neuroblastoma with dissemination to retroperitoneal and mesenteric lymph nodes. CECT chest showed a heterogeneously enhancing mass of the nodes with fibronodular and atelectatic lesions in the right middle lobe of the lung. The rest of the lung parenchyma was unremarkable with no evidence of pleural or pericardial effusion. The TB-IGRA Quantiferon (tuberculosis-gamma interferon release assay) assay was negative. An ultrasound-guided FNAC was performed from the abdominal mass, and FNAC was also done from the supraclavicular node. Both aspirates showed similar cytological features. Smears were highly cellular with the presence of atypical cells with high $\mathrm{N}: \mathrm{C}$ ratio, round to eccentrically placed nucleus with vesicular chromatin and prominent nucleoli. Few cells showed a moderate amount of eosinophilic granular cytoplasm (Fig. 1B). The atypical cells on immunohistochemistry stained positive for Synaptophysin and Melan-A (inset). In view of the above features, the possibility of an adrenocortical carcinoma versus neuroblastoma with metastatic disease was suggested. During this course, the patient developed severe dyspnoea and underwent a debulking surgery. Intraoperatively, a tumour was seen displacing the left kidney downwards with multiple lymph nodes encasing major vessels. The patient developed acute respiratory distress postoperatively and succumbed to the disease.

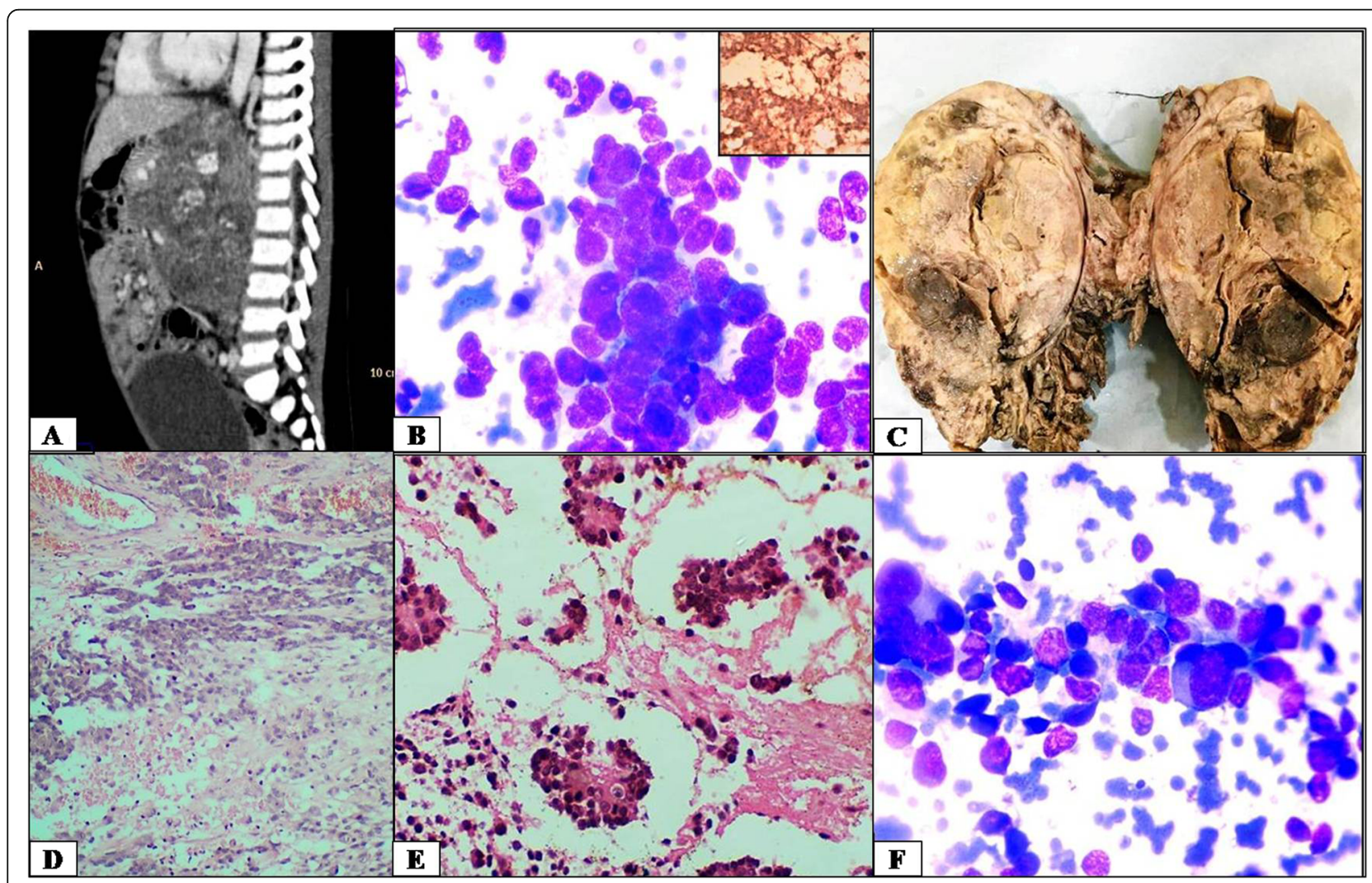

Fig. 1 A CECT abdomen shows a suprarenal heterogeneous mass with stippled calcification encasing major vessels. B Cellular fragments showing large atypical cells having moderate cytoplasm, pleomorphic nuclei and prominent nucleoli forming acini. (Giemsa, 400X). Inset: Melan A positive tumor cells (Immunocytochemistry, 400X, DAB as chromogen). C Adrenal mass showing solid, variegated lesion with large areas of necrosis and haemorrhage. D Microscopy shows a viable malignant tumor with geographical areas of necrosis, E Tumor cells forming rosettes (Hematoxylin \& Eosin, 100X), F Reviewed cytology smears showing two population of cells (Giemsa, 400X) 
Grossly, the specimen measured $14 \times 10 \times 9 \mathrm{~cm}$ and weighed $280 \mathrm{~g}$. It was well-circumscribed, partially encapsulated with a variegated, solid cut surface showing large areas of necrosis and haemorrhage. A rim of compressed adrenal tissue was identified at the periphery (Fig. 1C). Microscopy showed large geographical areas of necrosis with the presence of viable tumour in between (Fig. 1D). The tumour cells displayed marked nuclear atypia, open chromatin and frequent mitotic figures including atypical ones. At places, they were smaller and were seen forming rosettes (Fig. 1E). The cells showed immunoreactivity for Synaptophysin, Melan-A and Chromogranin and were negative for HMB- 45 and pancytokeratin. Capsular and vascular invasion was also identified. All features combined, a final diagnosis of mixed cortico-medullary carcinoma was concluded, and cytology slides were reviewed. Careful evaluation of cytology smears showed a dual population of cells. There was one cell type which was large atypical polygonal with opened up chromatin and granular cytoplasm. The other distinct cell type was a small round with scant agranular cytoplasm, dense chromatin and arranged in acini or rosettes (Fig. 1F). Mitotic figures were common amongst the larger cells. The foci of necrosis were also seen. A cyto-histological correlation was established.

\section{Discussion}

The adrenal gland is composed of the cortex (mesodermal) and medulla (ectodermal origin). Adrenocortical carcinoma arises from the adrenal cortex and is an uncommon malignancy with an incidence of 1-2 per million per year in the adult population [5]. Pheochromocytomas arising from the medulla are also relatively uncommon with an incidence of 2-8 per million per year [6]. These tumours have a female predilection with a median age of 50-60 [7-9]. Mixed cortico-medullary tumours comprised both cell types [7]. Few theories explaining their origin have been proposed. The most common view is the collision theory, which highlights their separate embryological origin [2]. Others state the presence of a hybrid population of cells in early foetal life or a genetic defect during intrauterine life [2]. Despite these theories, etiopathogenesis is still unclear.

Computed tomography $(\mathrm{CT})$ is the radiological investigation of choice for adrenal masses as it allows high spatial resolution with pre- and post-contrast images. Magnetic resonance imaging (MRI) also has several advantages like higher contrast, multiplanarity, and chemical shift imaging, which better delineate the tumour [10].

Distinguishing benign from malignant lesions in endocrine organs is a major diagnostic challenge. Generally, lesions less than $20 \mathrm{~g}$ are usually benign, and more than $4500 \mathrm{~g}$ are obvious carcinomas. Borderline sized tumours, especially when found in the paediatric age group, pose a significant problem in diagnosis. Microscopic features favouring malignancy include large size, tumour necrosis and variegated nodular appearance [1].

The mixed tumours are mainly benign, with only three cases of mixed cortico-medullary adrenal carcinoma (MCMAC) reported in the medical literature to date even in adults (Table 1). The clinical presentation described in the literature varies from mild abdominal pain, abdominal mass, diabetes, hypertension and Cushing's syndrome $[2,3]$.

Adrenal malignancies in children mimic Wilm's tumour, renal cell carcinoma, composite pheochromocytoma, adrenal cortical adenoma with medullary hyperplasia, and metastatic carcinoma [2]. IHC markers like Melan-A, BCL-2, Inhibin-A, Calretinin, mitochondrial antigen 113-1 and SF 1 are useful markers of cortical differentiation and Synaptophysin, Chromogranin for medullary differentiation, and S100 for sustentacular cells $[1,2]$. These tumour cells are negative for vimentin, cytokeratin, ACTH, calcitonin, serotonin and somatostatin. Three components on microscopy characterise Wilm's tumour: blastemal, epithelial and stromal and show immunopositivity for WT1, PAX8, vimentin and EMA. Renal cell carcinoma is uncommon in children, however, characterised by immunopositivity for CD10 and EMA [7-11]. Classical pheochromocytoma is derived from the adrenal medulla. Composite pheochromocytoma is an uncommon tumour composed of pheochromocytoma and neurogenic tumours and it is very difficult to differentiate the two clinically and radiologically. Composite pheochromocytoma shows positive IHC for Chromogranin, S-100 and Neurofilament $1[1,9,11]$. Thus, the diagnosis of composite pheochromocytoma is made mainly based on histomorphology and immunohistochemistry. An adrenal cortical adenoma is a benign tumour usually due to excessive secretion of adrenocorticotropic hormone from the anterior pituitary. Adrenal medullary hyperplasia is an entity characterised by excessive secretion of catecholamines [1, 2, 9]. Distant metastasis and surrounding tissue infiltration are definitive evidence for malignancy. In the absence of these along with the intermediate size and suspicious features, it may be difficult to differentiate an adrenal cortical carcinoma from adenoma. The diagnosis in such a scenario requires a multiparametric approach, including various histological features. Amongst histopathological criteria, the Weiss System is the most commonly used. It requires four or more criteria out of the nine criteria for labelling a tumour as malignant. The nine histological criteria are (i) high nuclear grade, (ii) mitotic rate greater than five per 50 high power fields (HPF), (iii) atypical mitotic figures, (iv) 
Table 1 Details of previously reported MCMA carcinoma along with a current case in the medical literature

\begin{tabular}{|c|c|c|c|c|c|c|c|c|c|}
\hline Year & Age & Sex & $\begin{array}{l}\text { Clinical } \\
\text { features }\end{array}$ & Biochemical & $\begin{array}{l}\text { Urinary } \\
\text { findings }\end{array}$ & Cytology & Gross & Histopathology & Prognosis/survival \\
\hline 2012 & 78 & $\mathrm{~F}$ & $\begin{array}{l}\text { Dizziness } \\
\text { Hypertension }\end{array}$ & $\begin{array}{l}\text { Elevated serum } \\
\text { DHEA } 571 \mathrm{mg} / \\
\text { dL }(N<200)\end{array}$ & $\begin{array}{l}\text { Elevated urine } \\
\text { metanephrines } \\
457 \mu \mathrm{g} / 24 \mathrm{~h}(\mathrm{~N} \\
24-96 \mu \mathrm{g} / 24 \mathrm{~h})\end{array}$ & Not done & Not available & $\begin{array}{l}\text { IHC staining for } \\
\text { chromogranin A, } \\
\text { synaptophysin, } \\
\text { Melan-A and inhibin } \\
\text { positive. } \\
\text { S-100 - sustentacular } \\
\text { cells. }\end{array}$ & $\begin{array}{l}121 \text { days follow-up } \\
\text { was uneventful later } \\
\text { developed } 8.5 \mathrm{~cm} \\
\text { sized mass adjacent to } \\
\text { the adrenalectomy } \\
\text { site. } \\
\text { Liver mass measuring } \\
1.7 \mathrm{~cm}+\text {. }\end{array}$ \\
\hline 2013 & 63 & M & $\begin{array}{l}\text { Mass effect } \\
\text { Abdominal } \\
\text { pain } \\
\text { Weight loss }\end{array}$ & $\begin{array}{l}\text { Morning } \\
\text { cortisol, } 661 \\
\text { nmol/L }(n= \\
171-536) \\
\text { NSE (ng/mL), } \\
20.33(<12.5) \\
\text { Chromogranin } \\
\text { A, } 21 \mathrm{ng} / \mathrm{mL} \text { ( } \\
=2-18) \\
\text { Morning cortisol } \\
\text { after } 1 \mathrm{mg} \\
\text { overnight } \\
\text { dexamethasone } \\
\text { suppression test, } \\
\text { 100 nmol/L ( } n< \\
\text { 50) }\end{array}$ & $\begin{array}{l}\text { Urine } \\
\text { catecholamines, } \\
150 \mathrm{~g} / 24 \mathrm{~h} \mathrm{(10-} \\
280)\end{array}$ & Not done & Not available & $\begin{array}{l}\text { The neoplastic cells } \\
\text { were positive for } \\
\text { chromogranin A, } \\
\text { synaptophysin, NSE, } \\
\text { vimentin and S-100 } \\
\text { and were focally posi- } \\
\text { tive for calretinin and } \\
\text { CKAE1/AE3 }\end{array}$ & $\begin{array}{l}\text { Radiology and } \\
\text { laboratory follow-up } \\
\text { in } 1 \text { year. Then, the } \\
\text { patient died } 18 \\
\text { months post- } \\
\text { surgery-respiratory } \\
\text { failure due to diffuse } \\
\text { pulmonary } \\
\text { metastases. }\end{array}$ \\
\hline 2016 & 50 & M & $\begin{array}{l}\text { Mass effect } \\
\text { Abdominal } \\
\text { pain } \\
\text { Weight loss }\end{array}$ & $\begin{array}{l}\text { Morning } \\
\text { cortisol, } 24.34 \\
\mu \mathrm{g} / \mathrm{dL}(n=6.2- \\
\text { 19.4). }\end{array}$ & $\begin{array}{l}\text { Urine free } \\
\text { cortisol, } 151.28 \\
\mu \mathrm{g} / 24 \mathrm{~h}(n= \\
36-137) \\
\mathrm{ACTH}<1.00 \mathrm{pg} / \\
\mathrm{mL}(n=7.2- \\
63.3) . \\
\text { VMA in } 24 \mathrm{~h} \\
\text { urine, } 4.3 \mathrm{mg} / 24 \\
\mathrm{~h}(n=1.9-9.8) .\end{array}$ & Not done & $\begin{array}{l}\text { Well-defined } \\
\text { encapsulated, } \\
\text { solid with a } \\
\text { little fat } \\
\text { weight } 2100 \mathrm{~g} \\
\text { and measured } \\
22 \mathrm{~cm}\end{array}$ & $\begin{array}{l}\text { Undifferentiated high- } \\
\text { grade carcinoma. } \\
\text { Tumour necrosis, } \\
\text { multinucleated and } \\
\text { bizarre cells+. } \\
\text { Mitoses 50/hpf. } \\
\text { Focal vascular } \\
\text { invasion. } \\
\text { No capsular invasion. } \\
\text { IHC - Inhibin, } \\
\text { Calretinin, } \\
\text { Chromogranin A and } \\
\text { S-100 markers are } \\
\text { positive. } \\
\text { Melan-A-negative. }\end{array}$ & $\begin{array}{l}18 \text { months after the } \\
\text { operation, the patient } \\
\text { developed liver } \\
\text { metastasis followed } \\
\text { by lung metastasis. }\end{array}$ \\
\hline $\begin{array}{l}\text { Present } \\
\text { case } \\
(2021)\end{array}$ & 2 & $\mathrm{~F}$ & $\begin{array}{l}\text { Abdominal } \\
\text { pain } \\
\text { Weight loss }\end{array}$ & $\begin{array}{l}\text { Morning } \\
\text { cortisol, } 35.2 \mu \mathrm{g} / \\
\mathrm{dL}\end{array}$ & $\begin{array}{l}\text { Urinary VMA } \\
2.76 \mathrm{mg} / 24 \mathrm{~h}(\mathrm{~N} \\
<2.20 \mathrm{mg} / 24 \mathrm{~h} \text { ), } \\
\text { urinary ketones } \\
\text { positive }\end{array}$ & $\begin{array}{l}\text { Dual } \\
\text { population } \\
\text { of cells }\end{array}$ & $\begin{array}{l}\text { Specimen } \\
\text { weighed } 280 \\
\mathrm{~g} \text { and } \\
\text { measures } 14 \\
\times 10 \times 9 \mathrm{~cm} \\
\text { Solid } \\
\text { Haemorrhage } \\
\text { and necrosis+ }\end{array}$ & $\begin{array}{l}\text { Malignant tumour } \\
\text { with geographical } \\
\text { areas of necrosis with } \\
\text { the presence of } \\
\text { viable tumour in } \\
\text { between. }\end{array}$ & $\begin{array}{l}\text { Died in post-operative } \\
\text { period due to acute } \\
\text { respiratory distress. }\end{array}$ \\
\hline
\end{tabular}

eosinophilic tumour cell cytoplasm (greater than 75\% tumour cells), (v) diffuse architecture (greater than $33 \%$ of tumour), (vi) necrosis, (vii) venous invasion, (viii). sinusoidal invasion and (ix) capsular invasion [12]. No reported molecular or cytogenetic analysis of MCMAC to date is known; the diagnosis rests upon histomorphology and immunohistochemistry.

There are very few case reports of this entity, making the prediction of clinical course and outcome very difficult. According to Michalaopoulous et al., the prognosis and median survival of MCMAC are poor and even worse than adrenocortical carcinoma. MCMAC shows positivity for both cortical and medullary markers, thus aiding diagnosis [3].

\section{Conclusions}

Coexistent malignant cortical and medullary adrenal tumour is an extremely uncommon phenomenon and carries a very grave prognosis. The case report aims at highlighting the cytological description of this entity and increasing its awareness in children, which can help establish an early preoperative diagnosis, clinical course and prognostication, though more cases need to be reported for guidelines on appropriate management and prognosis. 


\section{Abbreviations}

VMA: Vanillylmandelic acid; ESR: Erythrocyte sedimentation rate; CECT: Contrast-enhanced computed tomography; TB-IGRA Quantiferon: Tuberculosis-gamma interferon release assay quantiferon assay; FNAC: Fine needle aspiration cytology; MRI: Magnetic resonance imaging; CT: Computed tomography; MCMAC: Mixed cortico-medullary adrenal carcinoma

\section{Acknowledgements}

NA

\section{Authors' contributions}

All authors have read and approved the final manuscript. AK-preparation of the manuscript, review of the literature and reporting pathologist. NM-preparation and editing of the manuscript. NAK - treating surgeon and critical review of the manuscript. NG-reporting radiologist and critical review of the manuscript.

\section{Funding}

None

\section{Availability of data and materials}

Available upon request

\section{Declarations}

\section{Ethics approval and consent to participate}

The Institution Ethical Committee approved a waiver for the study in view of it being a retrospective case report. Verbal consent was also taken from the other authors.

\section{Consent for publication}

Written consent for participation was taken from the patient's parents as the patient is less than 16 years old.

Written informed consent was obtained from the patient's parents for publication of this case report, its details and accompanying images.

\section{Competing interests}

The authors declare that they have no competing interests.

\section{Author details}

'Department of Pathology, Chacha Nehru Bal Chikitsalaya, Room No.404, Fourth Floor, Geeta Colony, Delhi 110031, India. ${ }^{2}$ Department of Pediatric Surgery, Chacha Nehru Bal Chikitsalaya, Geeta Colony, Delhi 110031, India. ${ }^{3}$ Department of Radio-diagnosis, Chacha Nehru Bal Chikitsalaya, Geeta Colony, Delhi 110031, India.

Received: 26 May 2021 Accepted: 10 September 2021

Published online: 01 November 2021

\section{References}

1. Lloyd RV. Adrenal cortical tumors, pheochromocytomas and paragangliomas. Mod Pathol. 2011;24:S58-65.PMID: 21455202. https://doi. org/10.1038/modpathol.2010.126.

2. Alexandraki KI, Michail OP, Nonni A, Diamantis D, Giannopoulou I, Kaltsas GA, et al. Corticomedullary mixed adrenal tumor: case report and literature review. Endocr J. 2009;56:817-24.PMID: 19461165. https://doi.org/10.1507/ endocri.k09e-010.

3. Michalopoulos N, Pazaitou-Panayiotou K, Boudina M, Papavramidis T, Karayannopoulou G, Papavramidis S. Mixed corticomedullary adrenal carcinoma. Surg Today. 2013;43:1232-9. PMID: 23435808. https://doi.org/10.1 007/s00595-012-0458-4.

4. Alsabek MB, Alhmaidi R, Ghazzawi B, Hamed G, Alseoudi A. Mixed corticomedullary adrenal carcinoma - case report: comparison in features, treatment and prognosis with the other two reported cases. Int J Surg Case Rep. 2017;31:254-61.PMID:28199934. https://doi.org/10.1 016/j.jiscr.2017.01.010.

5. Libè R, Fratticci A, Bertherat J. Adrenocortical cancer: pathophysiology and clinical management. Endocr Relat Cancer. 2007:14:13-28. PMID: 17395972. https://doi.org/10.1677/erc.1.01130.
6. Golden SH, Robinson KA, Saldanha I, Anton B, Ladenson PW. Clinical review: prevalence and incidence of endocrine and metabolic disorders in the United States: a comprehensive review. J Clin Endocrinol Metab. 2009;94: 1853-78.PMID: 19494161. https://doi.org/10.1210/jc.2008-2291.

7. Donatini G, Van Slycke S, Aubert S, Carnaille B. Corticomedullary mixed tumor of the adrenal gland-a clinical and pathological chameleon: case report and review of literature. Updat Surg. 2013;65:161-4.PMID: 22228558. https://doi.org/10.1007/s13304-011-0132-1.

8. Ahmed AA. Adrenocortical neoplasms in young children: age as a prognostic factor. Ann Clin Lab Sci. 2009;39:277-82 PMID: 19667412.

9. Menon S, Mahajan P, Desai SB. Composite adrenal medullary tumor: a rare cause of hypertension in a young male. Urol Ann. 2011;3:36-8.PMID: 21346832. https://doi.org/10.4103/0974-7796.75860.

10. Albano D, Agnello F, Midiri F, Pecoraro G, Bruno A, Alongi P, et al. Imaging features of adrenal masses. Insights Imaging. 2019:25:10-1.PMID: 30684056. https://doi.org/10.1186/s13244-019-0688-8.

11. Zhang P, Genega E, Tomaszewski JE, Pasha TL, Livolsi VA. The role of calretinin, inhibin, Melan-A, BCL-2, and C-kit in differentiating adrenal cortical and medullary tumors: an immunohistochemical study. Mod Pathol. 2003;16:591-7.PMID: 12808065. https://doi.org/10.1097/01.MP.0000073134. 60541.E8.

12. Weiss LM. Comparative histologic study of 43 metastasising and nonmetastasizing adrenocortical tumors. Am J Surg Pathol. 1984;8:163-9. PMID: 6703192. https://doi.org/10.1097/00000478-198403000-00001.

\section{Publisher's Note}

Springer Nature remains neutral with regard to jurisdictional claims in published maps and institutional affiliations.

\section{Submit your manuscript to a SpringerOpen ${ }^{\circ}$ journal and benefit from:}

- Convenient online submission

- Rigorous peer review

- Open access: articles freely available online

- High visibility within the field

- Retaining the copyright to your article

Submit your next manuscript at $\boldsymbol{\nabla}$ springeropen.com 